\section{Mutasjon}

\section{i transportørgen kan gi ketoacidose}

Mutasjoner i et monokarboksylattransportørgen hindrer at ketonlegemer fra lever kan nyttes i andre deler av kroppen, noe som kan forklare utvikling av ketoacidose av ukjent årsak.

Når cellene tar opp for lite glukose, som ved sult eller uregulert diabetes, lager leveren ketonlegemer. Dette er alternative substrater for energiproduksjon i cellene, men når de ikke brukes opp fort nok, oppstår en potensielt dødelig ketoacidose.

Monokarboksylattransportører (MCT) sørger normalt for at ketonlegemer kommer ut av levercellene og inn i celler som kan forbrenne dem. I en studie som nylig er publisert i The New England Journal of Medicine beskrives mutasjoner i MCT1genet som en tidligere ukjent årsak til ketoacidose (1). Forfatterne identifiserte åtte ulike mutasjoner med tap av MCTfunksjon blant 96 barn uten diabetes som alle hadde hatt ketoacidoseepisoder utløst av faste og/eller infeksjoner. Ketoacidosen ble opphevet ved tilførsel av bikarbonat og glukose. De hardest rammede pasientene hadde tegn på cerebral funksjonssvikt.

Som påpekt $\mathrm{i}$ en lederartikkel i samme nummer, finnes MCT1-proteinet i mange celler i kroppen og kontrollerer bl.a. opptak av ketonlegemer og laktat i hjernen (2). Tap av MTC1-funksjon er også satt i forbindelse med epilepsi og andre hjernesykdommer, men dersom mutasjonen kun gir lett nedsatt funksjon, kan den forbli uoppdaget.

- MCT1-mutasjoner er en interessant og nyoppdaget mekanisme for utvikling av ketoacidose, sier professor Kristian F. Hanssen ved Oslo Diabetes Research Centre. - Oppdagelsen kan kanskje også forklare ulik tendens til ketoacidose hos diabetespasienter, selv om insulinmangel (absolutt eller relativ) fortsatt er det sentrale, sier Hanssen.

\section{Linda Hildegard Bergersen \\ Universitetet i Oslo}

\section{Litteratur}

1. van Hasselt PM, Sacha Ferdinandusse S, Monroe GR et al. Monocarboxylate transporter type 1 deficiency and ketone utilization. N Engl J Med 2014; akseptert for publisering.

2. Bergersen LH, Eid T. Monocarboxylate transport matters. N Engl J Med 2014; akseptert for publisering.

\title{
Ebolaepidemien i Vest-Afrika
}

\author{
Den pågående ebolaepidemien har allerede rammet flere mennesker \\ enn alle tidligere kjente ebolaepidemier til sammen, og estimater tilsier \\ at hundretalls til tusentalls nye mennesker vil bli smittet ukentlig i de \\ nærmeste månedene.
}

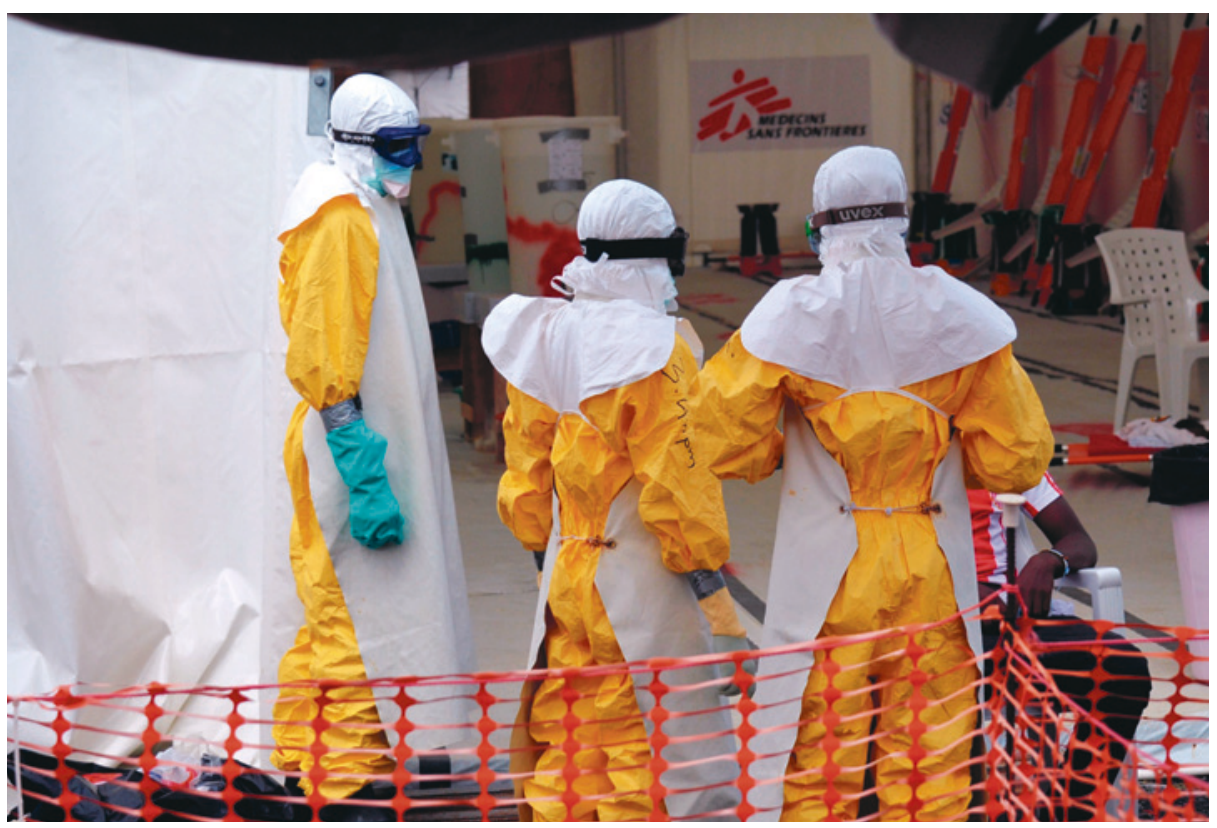

Helsearbeidere ved et behandlingssenter for ebola i Liberia. Foto: AFP photo/Zoom Dosso/NTB scanpix

En rapport fra Verdens helseorganisasjons ekspertgruppe på ebola inneholder data om epidemiens første ni måneder, fra desember 2013 til september 2014 (1). I denne perioden er 4507 bekreftede eller sannsynlige tilfeller av ebola rapportert, hvorav 2296 har vært fatale. Det antas at det er stor grad av underrapportering, slik at reelt antall rammede sannsynligvis er betydelig høyere. Medio september ble antall affiserte doblet på 15,7 dager i Guinea og 30,2 dager i Sierra Leone. Med uendret tempo skulle 20000 mennesker ha blitt smittet innen 2. november 2014. Oppdatert statistikk har imidlertid vist 13567 rapporterte tilfeller per 31. oktober 2014 (2).

De vanligst rapporterte symptomene var feber $(87,1 \%$ av pasientene), slapphet $(76,4 \%)$, nedsatt appetitt $(64,5 \%)$, oppkast $(67,6 \%)$, diaré $(65,6 \%)$, hodepine $(53,4 \%)$ og magesmerter $(44,3 \%)$. Dødelighet vurdert ved å dividere antall døde på antall smittede, ga en lavere andel enn det tidligere epidemier har vist, men dette kan skyldes manglende oppfølgingsdata på mange pasienter. Da ekspertgruppen kun så på individer med kjent utfall, ble fataliteten beregnet til 70,8\% i Guinea, Liberia og Sierra Leone, men kun 45,5\% (basert på 11 tilfeller) i Nigeria.

Sykdommen smitter ved direkte kontakt med symptomatiske pasienter, og tidligere epidemier har man lyktes å stoppe gjennom grunnleggende smitteverntiltak, slik som isolering av pasienter. Arbeidsgruppen har ikke identifisert kliniske faktorer som skiller den pågående epidemien fra tidligere utbrudd, og de konkluderer med at dette utbruddets størrelse ikke først og fremst skyldes kjennetegn ved viruset, men samfunnsforhold og utilstrekkelige kontrolltiltak.

\section{Kristoffer Brodwall}

Institutt for global helse og samfunnsmedisin Universitetet i Bergen

\section{Litteratur}

1. WHO Ebola Response Team. Ebola virus disease in West Africa-the first 9 months of the epidemic and forward projections. N Engl J Med 2014; 371 $1481-95$.

2. WHO. Ebola response roadmap situation report. http://apps.who.int/iris/bitstream/10665/137424/1/ roadmapsitrep_310ct2014_eng.pdf?ua=1\&ua=1 (1.11.2014]

Publisert først på nett. 